\title{
Effect of attack angle on the flow around adjacent circular and rectangular prisms
}

\section{Hücum açısının temas halinde dairesel ve dikdörtgen prizma etrafındaki akış üzerine etkisi}

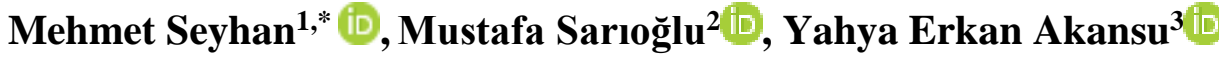 \\ 1,2 Karadeniz Technical University, Mechanical Engineering Department, 61080, Trabzon, Turkey \\ ${ }^{3}$ Niğde Ömer Halisdemir University, Mechanical Engineering Department, 51240, Niğde, Turkey
}

\begin{abstract}
An experimental investigation has been carried out to clarify the flow structure around adjacent circular and rectangular prisms. The measurements of hot-wire for $\mathrm{Re}=$ $4.1 \times 10^{3}, 9.0 \times 10^{3}$ and $1.5 \times 10^{4}$, lift and drag force for $\mathrm{Re}$ $=1.0 \times 10^{4}$, and in addition the flow visualization experiments for $\operatorname{Re}=2.3 \times 10^{3}$ have been performed in the range of $0^{\circ} \leq \alpha \leq 180^{\circ}$. The adjacent bodies consist of a circular cylinder having $9.5 \mathrm{~mm}$ diameter and a rectangular prism having $6 \mathrm{~mm} \times 10 \mathrm{~mm}$ cross-section attached to the circular cylinder from its short side in all the cases. The hot wire measurement results showed that the Strouhal number has Reynolds number independence for $\operatorname{Re}=4.1 \times 10^{3}$, $9.0 \times 10^{3}$, and $1.5 \times 10^{4}$. Sudden peaks in St and lift coefficients are obtained for a similar reason that is reattachment of the separated shear layer in the vicinity of $\alpha=60^{\circ}$ and $174^{\circ}$. For the adjacent bodies compared with the bare circular cylinder, $40 \%$, and $25 \%$ drag reduction is obtained at $\alpha=0^{\circ}$ and $174^{\circ}$, respectively. The obtained results show that the variations of lift coefficient, drag coefficient, and Strouhal number are strictly subjected to the attack angle.
\end{abstract}

Keywords: Adjacent bluff bodies, Circular cylinder, Rectangular prism, Vortex shedding, Drag coefficient

\section{Introduction}

Flow control around bluff bodies has been taken great attention by researchers due to having vital importance in daily life, industrial and aeronautics areas. Moreover, the collapse of Tacoma Narrows bridge [1] and three of eight cooling towers at the Ferrybridge [2-3] have aroused attention in order to take precaution and/or solve this problem that is resulting in aerodynamic phenomena such as vortex shedding producing periodic lift and drag force. Basic problems of bluff bodies, such as circular [4-7] and square cylinder [8-11], have been extensively studied in the literature. Vortex shedding is well known for these cases, but this type of bluff body is generally not found alone in real life cases. Therefore, in order to better elucidate flow structure around multiple bluff bodies configuration such as two or more side by side [3-12-14], tandem [15-17],
Özet

Temas halindeki dairesel ve dikdörtgen prizmalar etrafındaki akış yapısını aydınlatmak için deneysel bir araştırma yapılmıştır. $\mathrm{Re}=4.1 \times 10^{3}, 9.0 \times 10^{3}$ ve $1.5 \times 10^{4}$ için kızgın telle hız, $\operatorname{Re}=1.0 \times 10^{4}$ için kaldırma ve sürüklenme kuvveti ölçümleri ve ayrıca $\operatorname{Re}=2.3 \times 10^{3}$ için akış görüntüleme deneyleri $0^{\circ} \leq \alpha \leq 180^{\circ}$ aralığında gerçekleștirilmiştir. Temas halindeki cisimler, $6 \mathrm{~mm} \mathrm{x}$ $10 \mathrm{~mm}$ kesite sahip dikdörtgen bir prizma ile $9.5 \mathrm{~mm}$ çapına sahip dairesel bir silindirden oluşmaktadır. Kızgın tel ölçüm sonuçları, Strouhal sayısının $\mathrm{Re}=4.1 \times 10^{3}, 9.0 \times 10^{3}$ ve $1.5 \times 10^{4}$ sayıları için Reynolds sayısından bağımsız olduğunu göstermiştir. Kaldırma ve Strouhal sayılarındaki ani pikler akış ayrılma tabakasının $\alpha=60^{\circ}$ ve $174^{\circ}$ civarında yeniden tutunmasıyla ilgili aynı nedenden kaynaklanmaktadır. Temas halindeki cisimler ile sade silindir karşılaştırıldı ğında sürüklenme katsayısı $\alpha=0^{\circ}$ ve $174^{\circ}$ de sirasıyla $\% 40$ ve $\% 25$ azaltılmıştır. Elde edilen sonuçlar, kaldırma, sürüklenme katsayısı ve Strouhal sayısı değişimlerinin hücum açısına bağlı olduğunu göstermiştir.

Anahtar kelimeler: Temas halindeki cisimler, Dairesel silindir, Dikdörtgen prizma, Sürüklenme katsayısı, Strouhal say1s1

staggered [18-21], and combined [22-23] cylinders, the available literature related to this type of bluff bodies will be summarized.

Bearman and Wadcock [24] clarified the flow structure around two circular cylinders, arranged side by side at $\mathrm{Re}=$ $2.5 \times 10^{4}$. They also conducted surface pressure measurements to detect the pressure distribution around these cylinders and hot wire measurements to detect the vortex shedding frequency. When the distance between these cylinders is very small, its drag coefficient is less than that of the bare cylinder due to the base bleed. They also showed that the cylinders developed two vortex streets while the gap is bigger than 1d. For side by side circular cylinders, flow measurement experiment was researched by Alam and Zhou [12] at a Reynolds number of $4.7 \times 10^{4}$. They measured the pressure distribution around these circular cylinders at

\footnotetext{
* Sorumlu yazar / Corresponding author, e-posta / e-mail: mehmetseyhan@ktu.edu.tr (M. Seyhan)

Geliș / Recieved: 10.03.2021 Kabul / Accepted: 16.06.2021 Yayımlanma / Published: 27.07.2021

doi: $10.28948 /$ ngmuh. 894558
} 
$\mathrm{T} / \mathrm{d}=0.1$ and 0.2 . Surface oil flow visualization was implemented to obtain flow structure around these cylinders such as flow separation, reattachment, and stagnation point. Yen and Liu [14] experimentally investigated the flow structure around the square cylinder at $2262<\operatorname{Re}<28000$ in order to show the pressure distribution and vortex shedding frequency. They also separated the flow structure into three modes that are single, gap-flow, and couple vortex shedding modes to observe it by using the smoke wire flow visualization method. In the couple vortex shedding mode, they obtained two vortex streets as gap spacing between these cylinders $(\mathrm{g})$ is about bigger than 12 . In the gap-flow mode, minimum drag coefficient $\left(\mathrm{C}_{\mathrm{D}}\right)$ is obtained because of base bleeds with a similar reason to that observed at $\mathrm{g}=1$ by Bearman and Wadcock [24]. The maximum $C_{D}$ is observed at $\mathrm{g}=0$ for the single-mode. Alam and Zhou [13] researched the wake flow structure behind two side-by-side square cylinders with the help of the dye flow visualization method at $\mathrm{Re}=300$. They showed that the wake flow structure, based on the distance between cylinders, can be changed.

Force and hot-wire measurements and flow visualization experiments on two tandem circular cylinders having different diameters had been made by Alam and Zhou [25]. The results showed that the time-averaged drag on the downstream cylinder increased as the diameter ratio of the upstream and downstream cylinders was decreased. $\mathrm{Xu}$ and Zhou [26] especially focused on the Strouhal number, which is calculated from vortex shedding frequencies measuring via hot wire anemometer, at the wake of two tandem circular cylinder. They elucidated that the Strouhal number strictly was based on both L/d changing between $1-15$ and $\mathrm{Re}$ changing between $800-4.2 \times 10^{4}$. Alam and Sakamoto [20] measured the variation of the Strouhal number of a square and circular cylinder which are different arrangement such as tandem and staggered having a different angle and also analyzed it by using a wavelet transform method. The Flow structure around two circular cylinders arranged staggered was reported by Hu and Zhou [18] with the help of a hot wire anemometer, LIV and PIV methods. They also indicated that four different flow structures were aroused related to $\mathrm{L} / \mathrm{d}$ and angle of incidence ( $\alpha)$. Zhou et al. [21] investigated effects of Re (changing between $1.5 \times 10^{4}$ and $2 \times 10^{4}$ ), L/d (varied between 1.2 and 4 ) and $\alpha=0^{\circ}-90^{\circ}$ on the flow structure around two staggered circular cylinders. They also indicated that four different relationships between St-Re were obtained dependent on $\mathrm{L} / \mathrm{d}$ and $\boldsymbol{\alpha}$.

Yavuz et al. [23] investigated the effect of both two adjacent circular cylinders, and adjacent square and circular cylinder, rotating between $0^{\circ}$ and $180^{\circ}$ on vortex shedding frequencies. They indicated that change in St for these cases at the range between $0^{\circ}-150^{\circ}$ widely was independent on Reynolds number. In the study of Fleck [22], an experimental investigation of the effect of Re (ranging from $10^{4}$ to $5 \times 10^{4}$ ) and $\alpha$ (changing between $0^{\circ}$ and $180^{\circ}$ ) on the adjacent circular cylinder and rectangular, attached to the circular cylinder from its long side, was implemented. He also inspired from telephone drop wire to use as a test model.
The results showed that change in St was independent on $\mathrm{Re}$ for some specific angle of incidence.

According to the summarized literature above, there have been many studies having different arrangements, such as side by side, tandem, staggered, for two circular/square cylinder or circular and square cylinder configuration. But the available studies in the flow structure around adjacent circular and rectangular cylinders are very limited. This study extends studies related to the flow around the adjacent bodies performed by Yavuz et al. [23] and Fleck [22] to provide a different insight into the flow around the adjacent bodies consisting of a circular cylinder and rectangular cylinders. The purpose of the present study is to investigate the flow structure around the adjacent circular and rectangular cylinders capable of rotating between $0^{\circ}$ and $180^{\circ}$. For this purpose, the effects of the angle of incidence for three different Reynolds number were investigated by using hot-wire anemometer. Force measurement experiments were also carried out with the help of a load cell for $\operatorname{Re}=1 \times 10^{4}$.

\section{Material and method}

For this study, the experiments for the force measurement and the flow visualization are conducted in a suction type wind tunnel having a test section of $570 \mathrm{~mm}$ x $570 \mathrm{~mm}$ (WT1) in the Aerodynamics Research Laboratory (ARL) of Ömer Halisdemir University. Hot wire measurement experiments were also carried out in an open type of wind tunnel. This tunnel being in the Mechanical Engineering department at Karadeniz Technical University has a test section of $457 \mathrm{~mm} \times 457 \mathrm{~mm}$ (WT2). For both wind tunnels, the turbulent intensity is less than $1 \%$. The working sections of the tunnels have a divergence angle to obtain a uniform static pressure and compensate growing of the boundary layer along the longitudinal direction.

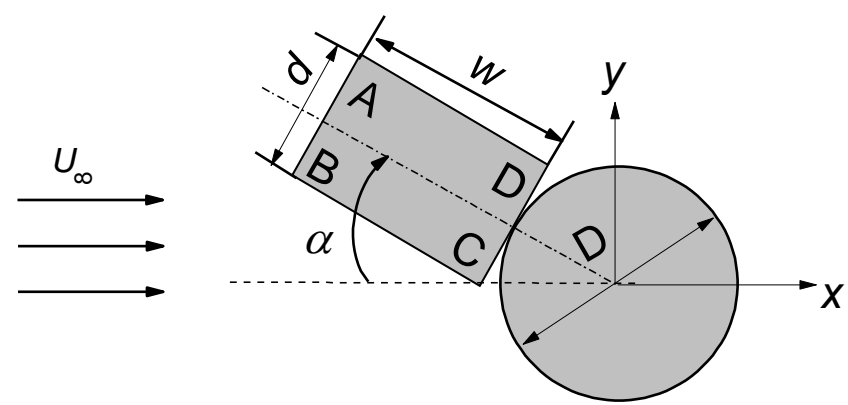

Figure 1. Test model geometries and coordinate system

As shown in Figure 1, the test model composes of two parts: the first one is a main circular cylinder having $9.5 \mathrm{~mm}$ diameter and the second one is a rectangular cylinder, having a $6 \mathrm{~mm} \times 10 \mathrm{~mm}$ cross-section, attached in all cases to the circular cylinder from its short side. In order to detect the vortex shedding frequency from these bluff bodies, the side of the rectangular cylinder and the diameter of the circular cylinder having been chosen as $6 \mathrm{~mm}$ and $9.5 \mathrm{~mm}$, respectively, while the adjacent bodies stand alone in air flow. The length of the test model for each tunnel is equal to the width of the tunnel test section due to the usage of two 
different wind tunnels. They also spanned along the entire width of the test section.

The rectangular cylinder was machined with sharp edges. The blockage ratios of the adjacent bodies are $4.3 \%$ for the WP2 at $\alpha=78^{\circ}$ and $102^{\circ}$ and $3.47 \%$ for the WP1 at $\alpha=78$ and $102^{\circ}$. For two models having different maximum blockage ratios of $6.3 \%$ and $12.6 \%$, Sarioglu et al. [27] showed that while the solid blockage has a small effect on the Strouhal number, geometric change with the attack angle has an important effect on the flow around a square prism with a plate. In the present study, the maximum blockage ratios of the model for each tunnel are smaller than $4.3 \%$ and therefore it is not necessary to correct the blockage effects. The model has a maximum projection height of $\mathrm{D}^{\prime}$ and a minimum aspect ratio for this case is 23.5. According to the suggestion of Wei and Chang [28], our test model can be accepted as a 2-dimensional model at this ratio.

A 3D schematic view consisting of a force and a hot-wire experimental setup, as shown in Figure 2, includes a test model, a load cell, a rotary unit, the test section, TSI IFA100 CTA, two hot-wire probe, a pitot-static tube, a micromanometer, a traverse control unit, a computer and $\mathrm{A} / \mathrm{D}$ acquisition board. The test model was centered and mounted vertically in the test section. The test model was attached to a computer controlled rotary unit so as to rotate it clockwise direction between $\alpha=0^{\circ}$ and $180^{\circ}$ with an increment of $3^{\circ}$. For $\mathrm{Re}=1.0 \times 10^{4}$, the force measurements were implemented by using a six component ATI Gamma DAQ F/T model load cell which is connected to the rotary unit. The data of drag and lift forces were acquired at a sample rate of $1000 \mathrm{~Hz}$ by means of NI PCIe-6323 DAQ card. For each measurement, 20000 data were collected, and the measurement duration was obtained during 20s. By averaging the measured data, mean drag and lift coefficients were calculated. For the flow visualization experiment, the test model and the rotary unit were horizontally mounted and rotated clockwise direction between $\alpha=0^{\circ}$ and $180^{\circ}$ with an increment of $15^{\circ}$ in this test section for Reynolds number of $2.3 \times 10^{3}$. For the hot wire measurement experiments, the adjacent model was centrally placed in the test section and rotated counterclockwise direction between $\alpha=0^{\circ}$ and $\alpha=$ $180^{\circ}$ with 3 -degrees increments. Vortex shedding from the adjacent model is detected by means of a TSI IFA 100 model constant temperature anemometer (CTA) using two hot-wire probes. More information about velocity measurement setup can be found in Yavuz et al. [23] and Sarioglu et al. [27]. For $\mathrm{Re}=4.1 \times 10^{3}, 9.0 \times 10^{3}$ and $1.5 \times 10^{4}$, vortex shedding frequency from velocity measurements were determined by using Fast Fourier Transform (FFT). The probes locations, that are $x / D=5$ and $15, y / D= \pm 2.5$ in the downstream of the body, are similar to the study of Yavuz et al. [23]. The velocity measurement data were collected as 4096 at a sampling frequency of $4 \mathrm{kHz}$.

The uncertainty of velocity measurements was calculated as $\pm 3 \%$. Moreover, the uncertainties in calculation of the Strouhal number and the vortex shedding frequency spectra are less than $\pm 3.3 \%$ and $\pm 0.5 \%$, respectively. The uncertainties of drag and lift coefficients were calculated as $6.7 \%$ and $8.8 \%$, respectively.

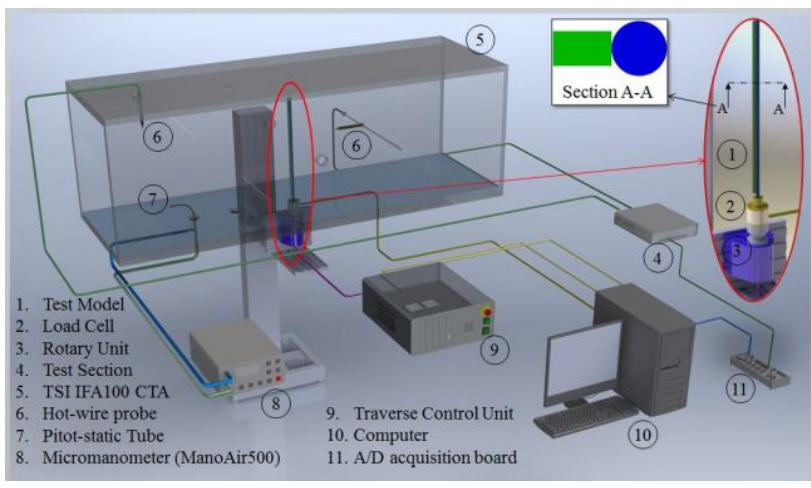

Figure 2. 3D schematic view of force and hot-wire experimental setup

\section{Results and discussion}

The vortex shedding around the adjacent test model was examined for $\operatorname{Re}=4.1 \times 10^{3}, 9.0 \times 10^{3}$ and $1.5 \times 10^{4}$. Spectral density of velocity fluctuations behind the model is given in Figure 3 for $\operatorname{Re}=9 \times 10^{3}$ at the angle of $30^{\circ}$. The dominant peak vortex shedding frequency is obtained as $\mathrm{f}=130 \mathrm{~Hz}$ from the test model. The St, based on $\mathrm{D}$, and $\mathrm{St}^{\prime}$, based on $\mathrm{D}^{\prime}$, denote the Strouhal numbers. $\mathrm{D}^{\prime}$ is projected height of the adjacent model. $\mathrm{D}^{\prime}$ used to reflect the scaling effect changing with attack angle and show the difference between D and D' that are utilized in calculation of Strouhal number.

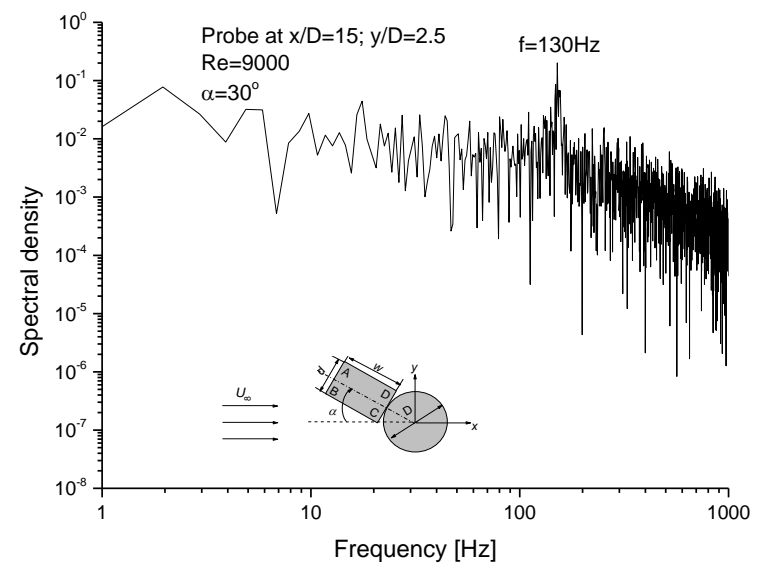

Figure 3. Spectral density of velocity fluctuations behind the model at $\alpha=30^{\circ}$ for $\operatorname{Re}=9.0 \times 10^{3}$.

Strouhal numbers, based on $\mathrm{D}$, versus attack angle for Re $=4.1 \times 10^{3}, 9.0 \times 10^{3}$ and $1.5 \times 10^{4}$ are given in Figure 4. This figure showed that the Strouhal number markedly change with the variation of the attack angle. Strouhal number abruptly diminishes in $0^{\circ} \leq \alpha \leq 20^{\circ}$ because the separated shear layer from the corner $\mathrm{A}$ of the rectangular cylinder shifts over the main cylinder and a wider wake region occurs. Due to the flow separation at sharp corners, Reynolds number has no significant influence on the Strouhal number. But, in the case of flow separation from the main circular cylinder at $\alpha=171^{\circ}$, the value of attack angle at maximum 
Strouhal number shifts with increasing Reynolds number. Maximum St is obtained as 0.24 at $\alpha=174^{\circ}$ for $\operatorname{Re}=$ $1.5 \times 10^{4}$. According to this figure, the change in St at $\alpha=0^{\circ}$ - $180^{\circ}$ is widely independent from Reynolds number for $\mathrm{Re}$ $=9.0 \times 10^{3}$ and $1.5 \times 10^{4}$. Moreover, independence of St-Re relationship is clearly seen for all $\operatorname{Re}$ at $\alpha=0^{\circ}-171^{\circ}$. This Reynolds independence was indicated that the flow structure around the adjacent circular and rectangular prism was not changed with increasing Reynolds number from $4.1 \times 10^{3}$ to $1.5 \times 10^{4}$ at nearly whole angle of attacks.

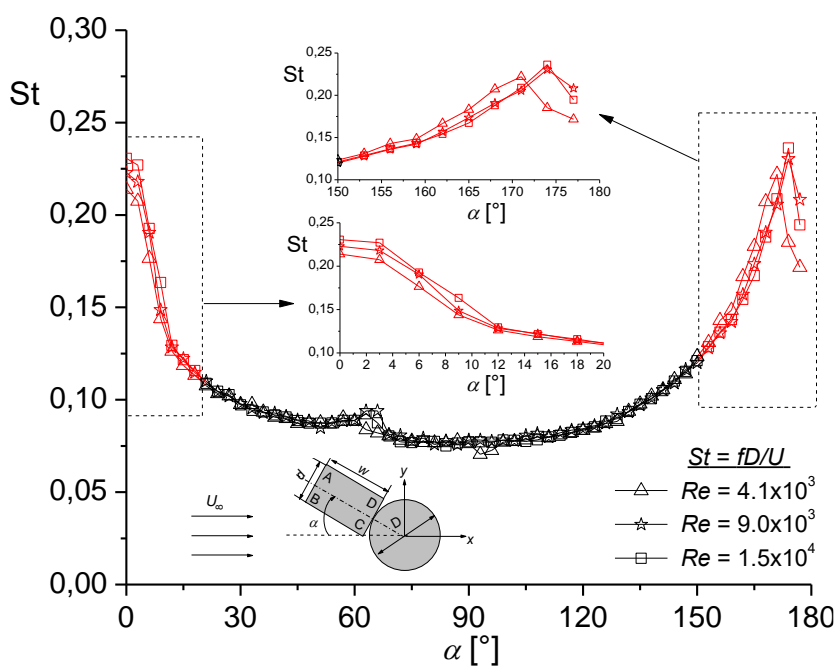

Figure 4. Strouhal number based on D vs attack angle.

Figure 5 shows the variation of $\mathrm{St}^{\prime}$, based on $\mathrm{D}^{\prime}$, versus the attack angle. For $\alpha=0^{\circ}$, maximum $\mathrm{St}^{\prime}$ is obtained because the separated shear layer from corner A and B reattach again on both the lower and upper side of the main cylinder. As the angle of incidence increases up to $\alpha=9^{\circ}$, a sharp decrease in the $\mathrm{St}^{\prime}$ is a cause of change in reattachment point and the separated shear layer from the corner A passes over the adjacent model without reattachment. The $\mathrm{St}^{\prime}$ gradually increases in the range $12^{\circ}$ to $60^{\circ}$ for all Re. Peak value of the $\mathrm{St}^{\prime}$ is obtained at $60^{\circ}$ for $\mathrm{Re}=4.1 \times 10^{3}, 63^{\circ}$ for $\operatorname{Re}=1.5 \times 10^{4}$ and $66^{\circ}$ for $\operatorname{Re}=9.0 \times 10^{3}$ because, the shear layers separated from corner B reattach near corner A. In the next angle for aforementioned each case, the reattachment of the separated shear layer finishes and, therefore, a sudden drop in $\mathrm{St}^{\prime}$ is seen. There is a significant peak in $\mathrm{St}^{\prime}$ which is associated with reattachment of the separated shear layer from the main cylinder at $168^{\circ}$ for $\operatorname{Re}=4.1 \times 10^{3}$ and $174^{\circ}$ for $\operatorname{Re}=9.0 \times 10^{3}$ and $1.5 \times 10^{4}$. After these angles, there is a significant decrease in $\mathrm{St}^{\prime}$ that is related to the disappearance of this reattachment.

Figure 6 shows a comparison of the Strouhal numbers $\left(\mathrm{St}^{\prime}\right)$ of the present study with together of those of Fleck [22] and Yavuz et al [23]. Fleck [22] used an adjacent model consisting of a circular cylinder and rectangular, attached to the circular cylinder from its long side by acquiring vortex shedding frequency at $0^{\circ} \leq \alpha \leq 20^{\circ}$ with an increment of $22.5^{\circ}$. $\mathrm{St}^{\prime}$ results of Fleck [22] is considerably course but present study results indicate the similar variation between $90^{\circ}$ and $157.5^{\circ}$ at $\operatorname{Re}=2 \times 10^{4}$. Yavuz et al [23] investigated the variation of Strouhal number of an adjacent model consisting of circular and square cylinder. Their results strikingly showed similar variation with the present study.

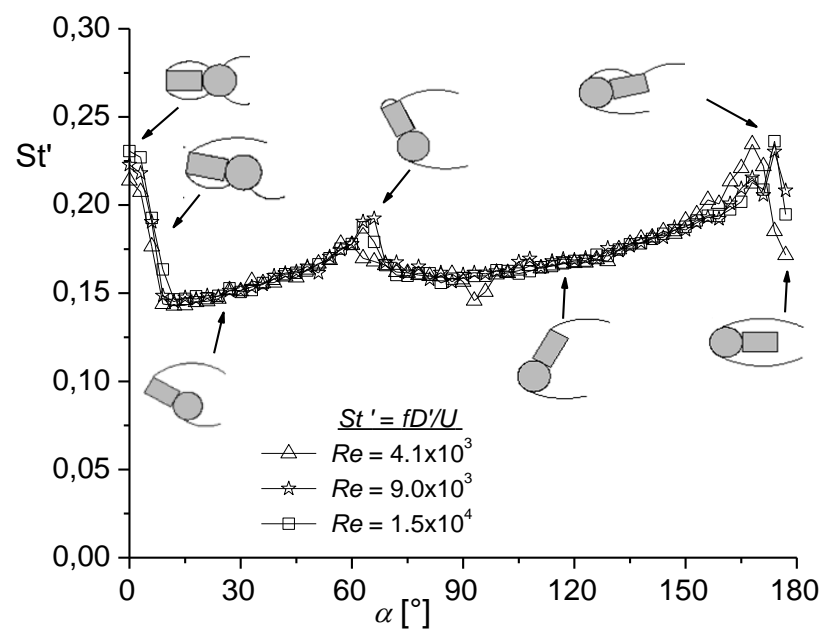

Figure 5. Strouhal number $\left(\mathrm{St}^{\prime}\right)$ based on $\mathrm{D}^{\prime}$ vs attack angle.

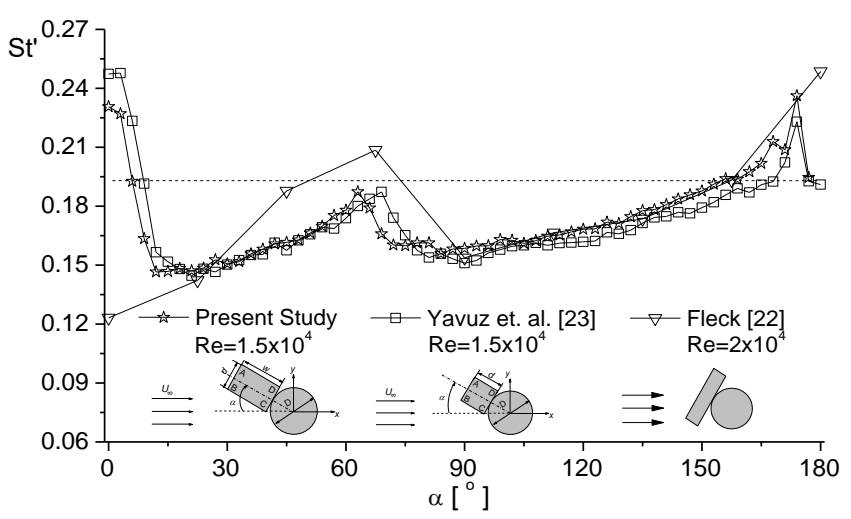

Figure 6. Comparison of Strouhal numbers with the studies of Yavuz et al. [23] and Fleck [22].

$\mathrm{C}_{\mathrm{D}}$ based on $\mathrm{D}$ and $\mathrm{C}_{\mathrm{D}}{ }^{\prime}$ based on $\mathrm{D}^{\prime}$ denote the drag coefficients. Comparison of the drag coefficients is plotted in Figure 7 as a function of the angle of incidence between $0^{\circ}$ and $180^{\circ}$. In the range $0^{\circ} \leq \alpha \leq 9^{\circ}$ and $171^{\circ} \leq \alpha \leq 180^{\circ}$, the drag coefficient for $C_{D}$ and $C_{D}^{\prime}$ has the same value due to having the same projected area of the adjacent bodies. For the adjacent bodies compared with the circular cylinder alone, $40 \%$ drag reduction is obtained at $\alpha=0^{\circ}$. Drag coefficient abruptly goes up with increasing the attack angle up to $51^{\circ}$ for $\mathrm{C}_{\mathrm{D}}$ and $36^{\circ}$ for $\mathrm{C}_{\mathrm{D}}{ }^{\prime}$ because of the increase in the wake width. $\mathrm{C}_{\mathrm{D}^{\prime}}$ slightly starts to decrease at $36^{\circ}$ and continue to decrease until $63^{\circ}$. The value of $\mathrm{C}_{\mathrm{D}}{ }^{\prime}$ at $63^{\circ}$ is the minimum value due to the reattachment near to the corner $\mathrm{A}$. $C_{D}$ shows the same trend with $C_{D}^{\prime}$ in the range $51^{\circ} \leq \alpha \leq 63^{\circ}$. After this angle, there is a sudden increase in both $C_{D}$ and $\mathrm{C}_{\mathrm{D}}{ }^{\prime}$ because the reattachment of the separated shear layer disappears and the wake width becomes larger. $C_{D}$ and $C_{D}{ }^{\prime}$ slightly increase in the range $69^{\circ} \leq \alpha \leq 84^{\circ}$ and $69^{\circ} \leq \alpha \leq$ $90^{\circ}$ respectively. The maximum drag coefficient is obtained 
as 3.68 for $\mathrm{C}_{\mathrm{D}}$ at $84^{\circ}$ and 1.78 for $\mathrm{C}_{\mathrm{D}}^{\prime}$ at $90^{\circ}$. Drag coefficient abruptly decreases with increasing of the angle of incidence between $90^{\circ}$ and $168^{\circ}$ associated with a decrease in the wake width behind the model. $\mathrm{C}_{\mathrm{D}}$ for the range $0^{\circ} \leq \alpha \leq 7.5^{\circ}$ and $153^{\circ} \leq \alpha \leq 180^{\circ}$, and $C_{D}$ for the range $0^{\circ} \leq \alpha \leq 7.5^{\circ}$ and $165^{\circ}$ $\leq \alpha \leq 180^{\circ}$ is smaller than that of the circular cylinder alone. For the adjacent bodies compared with the circular cylinder alone, $25 \%$ drag reduction is obtained because of the flow reattachment at $\alpha=174^{\circ}$.

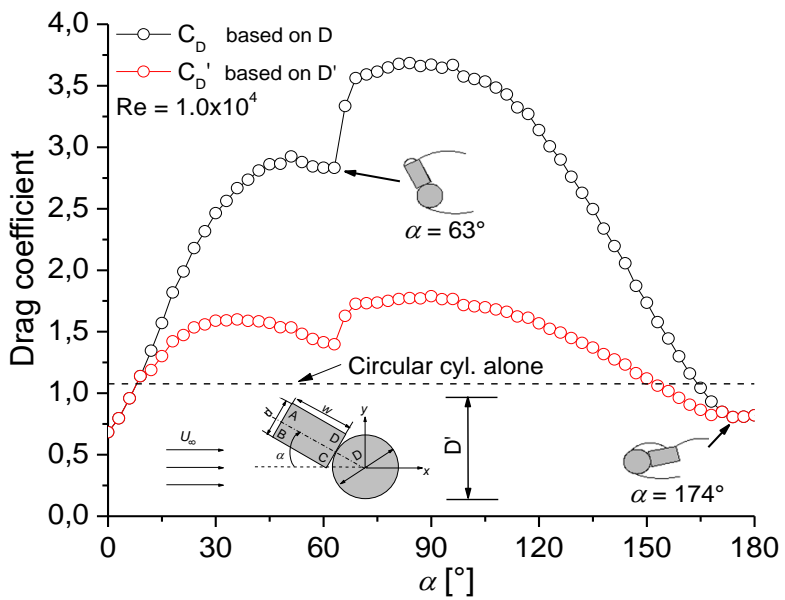

Figure 7. Variation of drag coefficient, based on D and $\mathrm{D}^{\prime}$, as a function of angle of incidence.

$\mathrm{C}_{\mathrm{L}}$ based on $\mathrm{D}$ and $\mathrm{C}_{\mathrm{L}}^{\prime}$ based on $\mathrm{H}^{\prime}$ denote the lift coefficients. The variation of the lift coefficients is plotted in Figure 8 as a function of the angle of incidence between $0^{\circ}$ and $180^{\circ}$. At $\alpha=0^{\circ}$, the lift coefficient is nearly obtained as 0 because of having the same flow structure in the upper and lower side of the test model. In the range $3^{\circ} \leq \alpha \leq 9^{\circ}$, there is little fluctuation in the lift coefficient that is attributed to the disappearance of reattachment of the separated shear layer. The maximum lift coefficient is obtained as 1.5 for $\mathrm{C}_{\mathrm{L}}$ at $\alpha=24^{\circ}$ and 0.86 for $\mathrm{C}_{\mathrm{L}}^{\prime}$ at $\alpha=60^{\circ}$. There is a sudden increase in $C_{L}$ and $C_{L}{ }^{\prime}$ between $9^{\circ}$ and $24^{\circ}$ because pressure differences between lower (high pressure) and upper surfaces (low pressure) of the model increase. At $\alpha=48^{\circ}$, the separated shear layer from the corner B slightly starts to approach towards corner $\mathrm{A}$ and later reattaches at $\alpha=60^{\circ}$ (As seen in Figure 8). After this angle $\left(\alpha=60^{\circ}\right)$, the lift coefficient sharply decreases up to $135^{\circ}$ for $\mathrm{C}_{\mathrm{L}}$ and $120^{\circ}$ for $\mathrm{C}_{\mathrm{L}}{ }^{\prime}$ owing to an increasing in surface pressure at the upper side of the model. The minimum lift coefficient is obtained as -2.12 for $C_{L}$ at $\alpha=135^{\circ}$ and -1.25 for $C_{L}{ }^{\prime}$ at $\alpha=120^{\circ}$. After these angles, the lift coefficients start to increase, which is attributed to the decrease in the wake width behind the model and the increase in pressure on the lower side of the model, up to $174^{\circ}$. At $\alpha=174^{\circ}$, the lift coefficient reaches again a peak value for $C_{L}$ and $C_{L}{ }^{\prime}$ because of a reattachment near the corner $\mathrm{B}$ on the $\mathrm{BC}$ surface. At $\alpha=$ $180^{\circ}$, lift coefficients is obtained nearly as 0 value resulting in pressure balance between the upper and lower side of the test model.
As shown in Figure 9, the flow visualization experiments were conducted at $0^{\circ} \leq \alpha \leq 180^{\circ}$ with an increment of $15^{\circ}$ for $\operatorname{Re}=2.3 \times 10^{3}$ to elucidate the flow structure around the adjacent model.

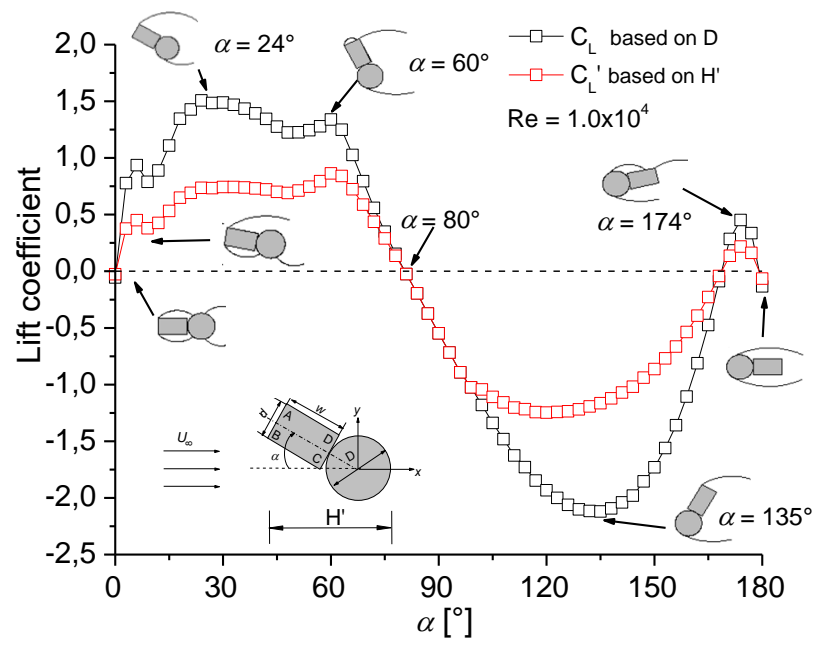

Figure 8. Variation of lift coefficient, based on D and $\mathrm{H}^{\prime}$, as a function of angle of incidence.

Flow phenomena such as stagnation point, flow separation, flow attachment, and reattachment are clearly shown in this figure. At $\alpha=0^{\circ}$, the incoming flow separates into two sides, that is up and down-side of the model, from the stagnation point in the front of the face $A B$ of the rectangular cylinder, and later the flows separate from the corner A and B. These separated shear layers reattach on both sides of the main cylinder. Shear layers separated two times from the rectangular and the main cylinders, respectively, produce both smaller vortices and the narrower wake behind the model. This also explains why the St and the $\mathrm{St}^{\prime}$ have the higher values shown in Figures 4 and 5, respectively. At $\alpha=15^{\circ}$, reattachment does not occur, therefore the wake region starts to enlarge. Wake width behind the model increases up to $90^{\circ}$. In the range $0^{\circ} \leq \alpha \leq$ $45^{\circ}$, the stagnation point, where the maximum pressure occurs, is in the middle of the $\mathrm{AB}$ surface and later it moves towards the corner $\mathrm{B}$ up to $45^{\circ}$. At $\alpha=60^{\circ}$, the stagnation point occurs on the $\mathrm{BC}$ surface, and the shear layer separated from corner B attaches at corner A. Therefore, in relation to this reattachment, there is a sudden increase in $\mathrm{St}^{\prime}$ for $\mathrm{Re}=$ $1.5 \times 10^{4}$ at $63^{\circ}$, in $C_{\mathrm{L}}$ and $\mathrm{C}_{\mathrm{L}}{ }^{\prime}$ for $\mathrm{Re}=1.0 \times 10^{4}$ at $60^{\circ}$ and also a sudden decrease in $\mathrm{C}_{\mathrm{D}}$ and $\mathrm{C}_{\mathrm{D}}{ }^{\prime}$ for $\mathrm{Re}=1.0 \times 10^{4}$ at $63^{\circ}$. The wake width increases while the stagnation point shifts from corner $\mathrm{B}$ to corner $\mathrm{C}$ in the range $45^{\circ}<\alpha \leq 90^{\circ}$. At $\alpha=90^{\circ}$, the wake is bigger than that of the other angles, and, therefore, the maximum $\mathrm{C}_{\mathrm{D}}{ }^{\prime}$, that can be seen from Figure 7 , is obtained 1.78 at this angle. After this angle, the wake width starts to decrease with increasing $\alpha$ that brought about a decrease in $C_{D}$ and $C_{D}{ }^{\prime}$ (Figure 7 ). The stagnation point occurs over the main cylinder at $\alpha=105^{\circ}$ and shift towards downside of it up to $180^{\circ}$. 

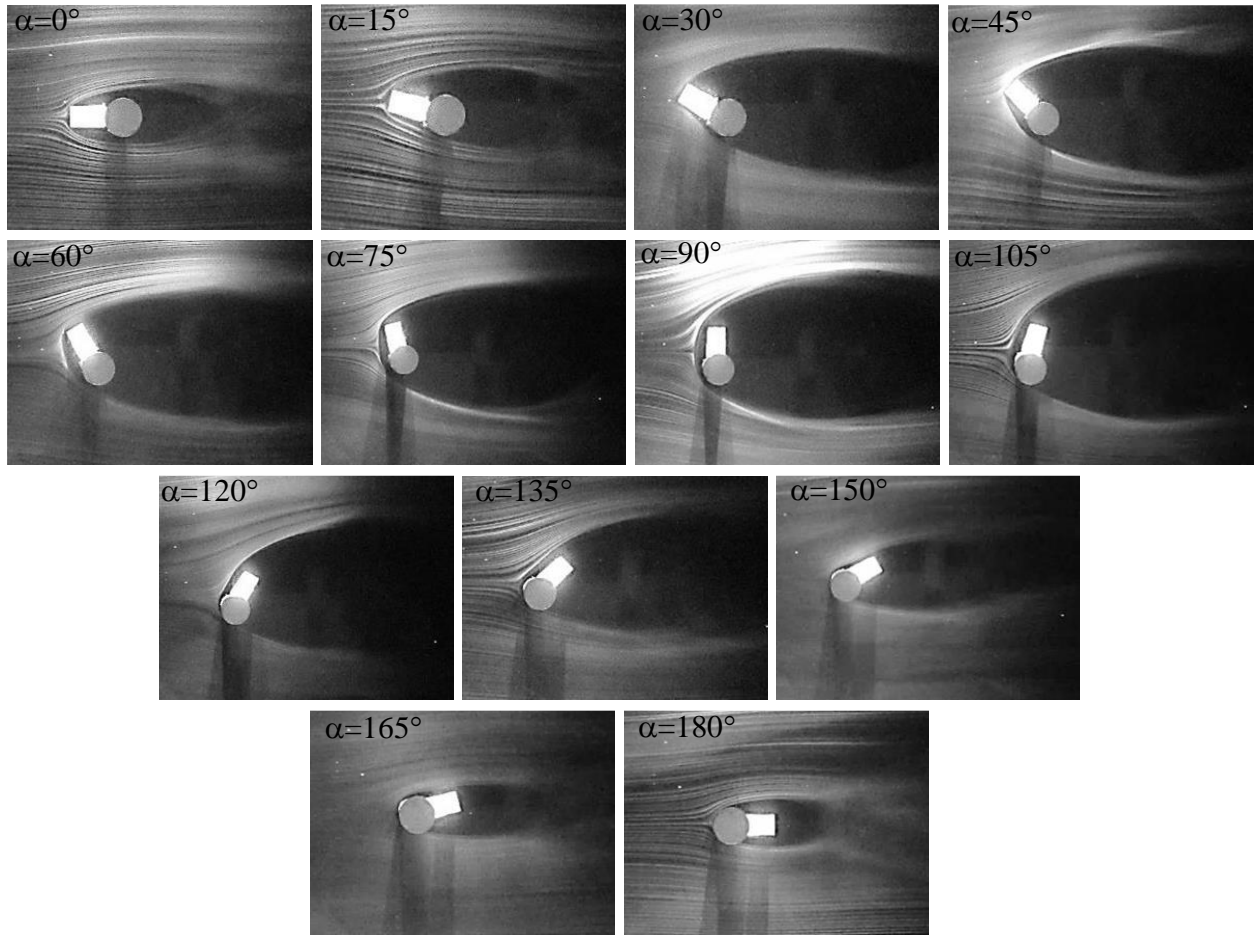

Figure 9. The Smoke-wire flow visualization of the flow around the model at $\operatorname{Re}=2.3 \times 10^{3}$.

\section{Conclusions}

An experimental investigation is conducted to investigate flow structure around the adjacent circular and rectangular cylinders. The measurements of the hot wire for $\mathrm{Re}=$ $4.1 \times 10^{3}, 9.0 \times 10^{3}$, and $1.5 \times 10^{4}$, the lift and drag forces for Re $=1.0 \times 10^{4}$, and the flow visualization for $\operatorname{Re}=2.3 \times 10^{3}$ have performed in the range of $0^{\circ} \leq \alpha \leq 180^{\circ}$. The remarkable findings for the flow around the adjacent circular and rectangular cylinders are summarized as follow:

- The results of the hot wire measurements show that Strouhal number has Reynolds number independence for $\operatorname{Re}=9.0 \times 10^{3}$ and $1.5 \times 10^{4}$. Moreover, there is an independence of St-Re relationship for all Reynolds number at $\alpha=0^{\circ}-171^{\circ}$.

- The $\mathrm{St}^{\prime}$, based on $\mathrm{D}^{\prime}$, provides better insight into the effect of flow phenomena such as flow separation, flow reattachment than the $\mathrm{St}$, based on $\mathrm{D}$ because $\mathrm{St}^{\prime}$ considers the exact projected height of the adjacent bodies.

- For the adjacent bodies compared with the circular cylinder alone, $40 \%$ drag reduction is obtained at $\alpha=0^{\circ}$ . $\mathrm{CD}^{\prime}$ for the range $0^{\circ} \leq \alpha \leq 7.5^{\circ}$ and $153^{\circ} \leq \alpha \leq 180^{\circ}$, and $C_{D}$ for the range $0^{\circ} \leq \alpha \leq 7.5^{\circ}$ and $165^{\circ} \leq \alpha \leq 180^{\circ}$ are smaller than that of the circular cylinder alone.

- The obtained results indicate that the variations of the Strouhal number, lift coefficient, and drag coefficient are strictly based on the attack angle.

\section{Conflicts of interest}

No conflict of interest was declared by the authors.
Benzerlik oranı (iThenticate): $\% 14$

\section{References}

[1] K. Y. Billah and R. H. Scanlan, Resonance, Tacoma Narrows bridge failure, and undergraduate physics textbooks. American Journal of Physics, 59, 118-124, 1991. https://doi.org/10.1119/1.16590.

[2] A. C. Khanduri, T. Stathopoulos and C. Bédard, Windinduced interference effects on buildings - a review of the state-of-the-art. Engineering Structures, 20617 630, $1998 . \quad \mathrm{https} / / /$ doi.org/10.1016/S01410296(97)00066-7.

[3] P. Burattini and A. Agrawal, Wake interaction between two side-by-side square cylinders in channel flow. Computers \& Fluids, 77, 134-142, 2013. https://doi.org/10.1016/j.compfluid.2013.02.014.

[4] A. Roshko, Experiments on the flow past a circular cylinder at very high Reynolds number. Journal of Fluid Mechanics, 10, 345-356, 1961. https://doi.org/10.1017/S0022112061000950

[5] Y. Bao and J. Tao, The passive control of wake flow behind a circular cylinder by parallel dual plates. Journal of Fluids and Structures, 37, 201-219, 2013. https://doi.org/10.1016/j.jfluidstructs.2012.11.002.

[6] S. Shukla, R. N. Govardhan and J. H. Arakeri, Flow over a cylinder with a hinged-splitter plate. Journal of Fluids and Structures, 25, 713-720, 2009. https://doi.org/10.1016/j.jfluidstructs.2008.11.004.

[7] E. A. Anderson and A. A. Szewczyk, Effects of a splitter plate on the near wake of a circular cylinder in 2 and 3-dimensional flow configurations. Experiments in Fluids, 23, 161-174, 1997. https://doi.org/10.1007/s003480050098. 
[8] T. Igarashi, Drag reduction of a square prism by flow control using a small rod. Journal of Wind Engineering and Industrial Aerodynamics, 69,141-153, 1997. https://doi.org/10.1016/S0167-6105(97)00150-5

[9] M. Sarioglu, Y. E. Akansu and T. Yavuz, Flow Around Rotatable Square Cylinder-Plate Body. AIAA Journal, 44, 1065-1072, 2006. https://doi.org/10.2514/1.18069.

[10] J. M. Chen and C. H. Liu, Vortex shedding and surface pressures on a square cylinder at incidence to a uniform air stream. International Journal of Heat and Fluid Flow, 20, 592-597, 1999. https://doi.org/10.1016/S0142-727X(99)00047-8.

[11] B. E. Lee, The effect of turbulence on the surface pressure field of a square prism. Journal of Fluid Mechanics, 69, 263-282, 1975.

[12] M. M. Alam and Y. Zhou, Flow around two side-byside closely spaced circular cylinders. Journal of Fluids and Structures, 23, 799-805, 2007. https://doi.org/10.1016/j.jfluidstructs.2006.12.002.

[13] M. M. Alam and Y. Zhou, Intrinsic features of flow around two side-by-side square cylinders. Physics of Fluids, 25, 085106, 2013 https://doi.org/10.1063/1.4817670.

[14] S. C. Yen and J. H. Liu, Wake flow behind two sideby-side square cylinders. International Journal of Heat and Fluid Flow, 32, 41-51, 2011. https://doi.org/http://dx.doi.org/10.1016/j.ijheatfluidfl ow.2010.09.005.

[15] D. Chatterjee and S. Amiroudine, Two-dimensional mixed convection heat transfer from confined tandem square cylinders in cross-flow at low Reynolds numbers. International Communications in Heat and Mass Transfer, 37, 7-16, 2010. https://doi.org/10.1016/j.icheatmasstransfer.2009.10.0 07.

[16] T. Zheng, S. K. Tang, B. Fei, C. Kung, T.-T. Liao, K.H. Tseng, K.-Y. Chen, M.-S. Chuang, K. Zarei and A. Y. Goharrizi, On the forces and strouhal numbers in the low reynolds number wakes of two cylinders in tandem. Transactions of the Canadian Society for Mechanical Engineering, $33 \quad 349 \quad$ (2009). https://doi.org/10.1139/tcsme-2009-0025.

[17] A. Sohankar and A. Etminan, Forced-convection heat transfer from tandem square cylinders in cross flow at low Reynolds numbers. International Journal for Numerical Methods in Fluids, 60, 733-751, 2009. https://doi.org/10.1002/fld.1909.

[18] J. C. Hu and Y. Zhou, Flow structure behind two staggered circular cylinders. Part 1. Downstream evolution and classification. Journal of Fluid Mechanics, 607, 51-80, 2008 . https://doi.org/10.1017/S0022112008001808.

[19] J. C. Hu and Y. Zhou, Flow structure behind two staggered circular cylinders. Part 2. Heat and momentum transport. Journal of Fluid Mechanics, 607, 81-107, $2008 . \quad$ https://doi.org/ 10.1017/S0022112008001808

[20] M. M. Alam and H. Sakamoto, Investigation of Strouhal frequencies of two staggered bluff bodies and detection of multistable flow by wavelets. Journal of Fluids and Structures, 20, 425-449, 2005. https://doi.org/10.1016/j.jfluidstructs.2004.11.003.

[21] Y. Zhou, S. X. Feng, M. M. Alam, and H. L. Bai, Reynolds number effect on the wake of two staggered cylinders. Physics of Fluids, 21, 125105, 2009. https://doi.org/10.1063/1.3275846.

[22] B. A. Fleck, Strouhal numbers for flow past a combined circular-rectangular prism. Journal of Wind Engineering and Industrial Aerodynamics, 89, 751755, 2001. https://doi.org/10.1016/S01676105(00)00087-8.

[23] T. Yavuz, Y. E. Akansu, M. SARIOĞLU and M. Özmert, Vortex Shedding on Combined Bodies at Incidence to a Uniform Air Stream. Proceedings of World Academy of Science Engineering and Technology, 41, 1095-1099, 2009.

[24] P. W. Bearman and A. J. Wadcock, The interaction between a pair of circular cylinders normal to a stream. Journal of Fluid Mechanics, 61499 (1973). https://doi.org/10.1017/S0022112073000832.

[25] M. M. Alam and Y. Zhou, Strouhal numbers, forces and flow structures around two tandem cylinders of different diameters. Journal of Fluids and Structures, 24, 505-526, 2008 https://doi.org/10.1016/j.jfluidstructs.2007.10.001.

[26] G. Xu and Y. Zhou, Strouhal numbers in the wake of two inline cylinders. Experiments in Fluids, 37, 248 256, 2004. https://doi.org/10.1007/s00348-004-0808-0.

[27] M. Sarioglu, Y. E. Akansu and T. Yavuz, Flow around a rotatable square cylinder-plate body. AIAA journal, 44, 1065-1072, 2006. https://doi.org/10.2514/1.18069.

[28] C.-Y. Wei and J.R. Chang, Wake and base-bleed flow downstream of bluff bodies with different geometry. Experimental thermal and fluid science, 26, 39-52, 2002. https://doi.org/10.1016/S0894-1777(02)00111-5 